\title{
Comparison of Structural and Noncompacted Soils for Trees Surrounded by Pavement
}

\author{
E. Thomas Smiley, Lisa Calfee, Bruce R. Fraedrich, and Emma J. Smiley
}

\begin{abstract}
Trees in areas surrounded by pavement often have inhospitable rooting environments, which shorten their useful life expectancy. This trial was established to compare five different soil treatment options under pavement. Snowgoose cherry (Prunus serrulata) and Bosque lacebark elm (Ulmus parvifolia) were planted into $5.4 \mathrm{~m}^{3}\left(189 \mathrm{ft}^{3}\right) \mathrm{of} \mathrm{medium}^{3}$ containing compacted soil, gravel/soil mixture, Stalite, Stalite/soil mixture, or noncompacted soil and covered with concrete. A variety of growth and health parameters were measured after 14 months. It was found that there was more trunk diameter growth with the noncompacted treatment than the Stalite and Stalite/soil treatments; more twig growth in the noncompacted and gravel/soil treatments than all others; higher relative chlorophyll rating in the noncompacted treatment than all others; and more root growth in the noncompacted treatment (elms only). Suspended pavement over noncompacted soils provided the greatest amount of tree growth and health and should be considered when designing urban planting sites for trees.
\end{abstract}

Key Words. Biobarrier; Bosque lacebark elm; CU Soil; geotextile; planting pits; Prunus serrulata; skeletal soil; Snowgoose cherry; soil compaction; Stalite; structural soil; suspended pavement; suspended sidewalks; Ulmus parvifolia; urban plaza; urban tree planting.

Although the benefits of trees to the urban environment are widely acknowledged, highly developed urban areas are detrimental to the trees themselves. Many factors such as air pollution, poor drainage, and damage by people or vehicles contribute to the short life expectancy for urban trees. However, the most limiting factor in the growth of urban trees is the lack of usable soil for root growth (Craul 1992).

To meet this challenge, several "structural" or "skeletal soils" have been developed as alternatives to the typical compacted soil required to bear the weight of pavement and vehicular traffic in urban areas. Researchers at Cornell University have experimented with a gravel and soil medium, consisting of $80 \%$ stone $20 \%$ soil (by weight) and a small amount of hydrogel to prevent the two from separating during mixing. Research suggests that this mixture, known as CU Soil is more beneficial to urban trees than standard compacted soil (Grabosky and Bassuk 1995; Grabosky et al. 1998; Grabosky et al. 2002).

Likewise, Carolina Stalite Company (Salisbury, NC, U.S.) developed a structural soil treatment using a porous expanded slate rock known as Stalite. This material can take the place of the solid rock used in the CU Soil and provide additional water and air storage capacity when mixed with $20 \%$ sandy clay loam (Costello and Jones 2003). Stalite and gravel/soil mixtures are both capable of meeting engineering requirements in urban areas by forming a stone matrix under the pavement. Meanwhile the soil found between the stones is noncompacted, leaving room for air exchange, water holding, and root growth. Research has shown that this model encourages roots to penetrate deeper into the ground rather than shifting the structural soil upward and causing pavement failures (Grabosky et al. 1998).

Another option is suspended pavement over noncompacted soil; this construction technique allows the use of higher usable soil volume under the pavement. The pavement may be either precast concrete lowered onto footers or concrete poured in place (Don McSween and James Urban, pers. comm.). Although structural soils only contain approximately $20 \%$ soil by volume, which may affect water and nutrient availability, suspended pavement can have nearly $100 \%$ of the soil volume in noncompacted soil.

Although research has been conducted on these structural soils individually, no comparison has been made of their gravel/soil mixture, Stalite, Stalite/soil mixture, and noncompacted soil installed under a suspended sidewalk. This experimental was developed to compare the ease of installation of each product, the impact of each treatment on tree growth, required maintenance practices, and the impact on the pavement over time. The results of the treatments in the first year of growth are reported in this article.

\section{MATERIALS AND METHODS}

Three trenches $6 \times 24 \mathrm{~m}(19.8 \times 79.2 \mathrm{ft})$ were completely excavated to a depth of $0.6 \mathrm{~m}(1.98 \mathrm{ft})$ at the Bartlett Tree Research Laboratory in Charlotte, North Carolina, U.S. during the spring of 2004. The trenches were lined with a thick 
geotextile (Typar Style 3801 g; BBA Fiberweb, Old Hickory, $\mathrm{TN})$ to contain root growth. In addition, sections $3 \times 3 \mathrm{~m}(9.9$ $\times 9.9 \mathrm{ft}$ ) were delineated using Biobarrier (BBA Fiberweb) to contain root growth from individual trees. Four adjacent $3 \times$ $3 \mathrm{~m}(9.9 \times 9.9 \mathrm{ft})$ sections were filled with the same soil medium to compose a treatment. One tree was planted in each $3 \times 3 \mathrm{~m}(9.9 \times 9.9 \mathrm{ft})$ section giving each tree approximately $5.4 \mathrm{~m}^{3}\left(189 \mathrm{ft}^{3}\right)$ of medium to grow in. Trees were set in the middle of each $3 \times 3 \mathrm{~m}(9.9 \times 9.9 \mathrm{ft})$ plot and soil was added in lifts around them and compacted using either a plate vibrator or impact compactor (Wacker Packer WP1550 vibratory plate compactor, Wacker Rammer BS600Y jumping jack compactor, respectively). Soil density was independently determined by S\&ME Inc., Charlotte, NC.

Treatments were as follows:

1. Gravel/soil mixture-comprised of $80 \%$ gravel 2.5 to $3.5 \mathrm{~cm}$ (1 to $1.4 \mathrm{in}$ ) diameter and $20 \%$ sandy clay loam soil. A hydrogel (Terrasorb, fine) was sprayed on the gravel before mixing with soil. Lifts were $20.3 \mathrm{~cm}(8.12$ in) thick and were compacted with an impact compactor to $95 \%$ Proctor.

2. Stalite/soil mixture-comprised of $80 \%$ Stalite 2 to 3.5 $\mathrm{cm}$ ( 0.8 to 1.4 in) diameter mixed with $20 \%$ sandy clay loam. Stalite was wetted before mixing with soil. Lifts were $30.5 \mathrm{~cm}$ (12.2 in) thick and compacted with a vibratory plate compactor to the manufacturer's specifications.

3. Stalite alone was installed in $30.5 \mathrm{~cm}$ (12.2 in) lifts and compacted with a vibratory plate compactor to the manufacturer's specifications.

4. Compacted soil—sandy clay loam was installed in 20.3 $\mathrm{cm}$ (8.12 in) lifts and compacted with an impact compactor to $95 \%$ Proctor.

5. Noncompacted soil with suspended pavement was installed in the existing sandy clay loam soil. Biobarrier was trenched $61 \mathrm{~cm}$ (24.4 in) deep to make $3 \times 3 \mathrm{~m}$ (9.9 $\times 9.9 \mathrm{ft}$ ) plots. The soil at this site was decompacted using a backhoe excavator after tree planting using the method proposed by Rolf (1994).

With the exception of the noncompacted treatment, each treatment was randomly assigned within a row, creating a randomized block design. As a result of the different construction techniques used in the noncompacted treatment, all of the noncompacted treatments were confined to a single row.

Concrete was installed over the plots leaving an $80 \mathrm{~cm}$ (32 in) round hole centered on each tree trunk. The concrete was $5 \mathrm{~cm}$ (2 in) thick near the center hole and gradually thickened toward the outside edge of the plot to $10 \mathrm{~cm}$ (4 in). In the noncompacted soil plot, $15.2 \mathrm{~cm}$ (6.1 in) diameter holes were augured $61 \mathrm{~cm}$ (24.4 in) deep to act as footer pilings, and $5 \mathrm{~cm}$ ( 2 in) of gravel was applied to the soil surface before installing the concrete.

In each treatment plot, two trees of two different species were planted for a total of four trees per treatment plot blocked by rows and randomly replicated three times for a total of 60 trees. The trees were Snowgoose cherry (Prunus serrulata) and Bosque lacebark elm (Ulmus parvifolia). These species were selected because they are medium-sized at maturity and root aggressively. Tree caliper was $5 \mathrm{~cm} \mathrm{(2}$ in) when installed. Wire baskets and burlap were removed from the top of the root balls at planting.

Bubbler irrigation was installed above the root ball, two bubblers on opposite sides of the trunk. Bubblers on treatments 1 and 2 were 0.5 gal per minute, treatment 3 were 1.0 gal per minute, and treatments 4 and 5 were 0.25 gal per minute. These flow rates were selected to maximize the water input and minimize soil surface runoff. Root ball soil moisture was monitored with tensiometers (Soil Moisture Equipment Corp., Santa Barbara, CA), one per treatment. When any two tensiometers reached 50 centibars of vacuum, the irrigation system was turned on for 5 minutes. During periods of drought, irrigation was applied daily. A drainage pipe was installed below the lower side of each row and run downhill to daylight.

Trunk caliper was measured with a diameter tape $30.5 \mathrm{~cm}$ (12.2 in) above grade. Twig growth was measured on five randomly selected branches of each tree. A Minolta SPAD 502 chlorophyll meter was used to determine relative chlorophyll content on five leaves selected at random around the crown of each tree. Foliar color and crown dieback were visually rated on a scale of 0 to 5 , with 0 being dead and 5 being completely healthy. Trunk borer counts were made by visual assessment and carefully cutting into the outer bark when necessary to determine if a borer was present. Borer counts are total number per treatment. Scale insects were rated on a visual scale of 1 to 5 , with 1 being scale-free and 5 being twigs completely covered with scale insects.

Rhizotrons were installed on one tree of each species per treatment. For the cherries, rhizotron windows were in direct contact with the treatment media. For elms, a $1.9 \mathrm{~cm}(0.76 \mathrm{in})$ layer of sand and peat mixture was installed between the clear Lexan window and the treatment media. This mixture was used to avoid clay and silt buildup on the window so as not to obscure root visibility over a long period of time. Rhizotrons were $61 \mathrm{~cm}$ (24.4 in) deep and $114 \mathrm{~cm}$ (45.6 in) wide, installed $1.5 \mathrm{~m}(4.95 \mathrm{ft})$ from the center of the tree trunk. Windows were kept covered with $1.9 \mathrm{~cm}$ (0.76 in) Styrofoam and $1.9 \mathrm{~cm}$ (0.76 in) plywood when not being assessed. Covers were used to keep light off the window and to buffer the temperature differences. Roots that grew to the point of touching the windows were diverted and grew along the surface of the glass. These roots were traced with a 
marker and measured with a rotary measuring wheel (Alvin, Germany).

Statistical analysis was conducted using SPSS (SPSS Inc., Chicago, IL) analysis of variance with Student-NewmanKeuls separation of mean $(P=0.05)$.

\section{RESULTS}

The fastest and simplest treatment to install was the Stalite treatment. It required only pouring the stone and using a vibratory compactor with fairly large lifts according to the manufacturer's instructions.

The noncompacted/suspended concrete treatments were second in speed and ease of installation. As a result of the location of this treatment, it was necessary to drive equipment over the existing soil. However, just before paving, the soil was decompacted with a backhoe. There was the additional step of drilling the footer holes and pouring concrete footer pilings, which adds to the time and cost of the treatment.
In the Stalite/soil mix treatment, the use of Stalite rather than a nonporous rock allowed wetting of the stone before mixing without the use of a hydrogel. This made mixing soil and stone much faster. Mixing and compacting the gravel/soil treatment was the most time-consuming.

Fourteen months after planting, there were distinct differences in tree growth, color, root growth, and crown dieback (Figure 1). With the cherries (Table 1), there was significantly more trunk diameter growth in the noncompacted/ suspended pavement treatment than with the Stalite and Stalite/soil treatments. Twig growth rates were significantly higher in the noncompacted/suspended pavement treatment than all other treatments. Visually, the foliar rating of the noncompacted/suspended pavement treatment, gravel/soil treatment, Stalite/soil treatment, and compacted treatment were all significantly better than the Stalite treatment. The mean SPAD reading of foliar color was significantly higher on the noncompacted/suspended pavement treatment than all

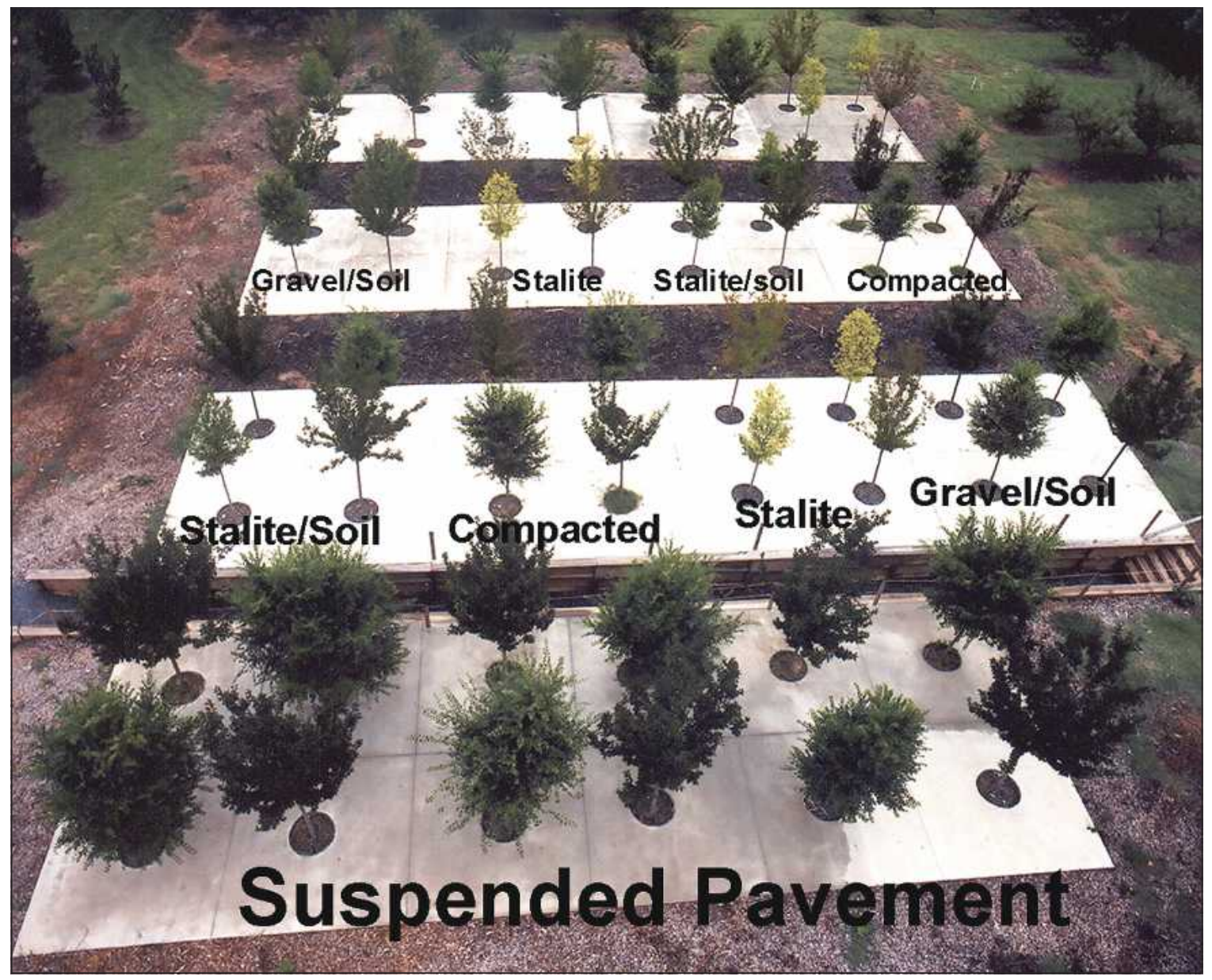

Figure 1. Research plot photographed from above in July 2005, approximately 14 months after plot establishment, labeled to show the different treatments: compacted soil, Stalite, Stalite/soil mixture, gravel/soil mixture, and suspended pavement over noncompacted soil. 
Table 1. Snowgoose cherry (Prunus serrulata) conditions 14 months after planting in $200 \mathrm{ft}^{3}$ of soil medium covered with concrete.

\begin{tabular}{|c|c|c|c|c|c|c|c|c|}
\hline Treatment & $\begin{array}{l}\text { Average } \\
\text { trunk } \\
\text { diameter } \\
(\mathrm{cm})\end{array}$ & $\begin{array}{l}\text { Average } \\
\text { diameter } \\
\text { change } \\
\text { since } \\
\text { planting } \\
(\mathrm{cm})\end{array}$ & $\begin{array}{l}\text { Average } \\
\text { twig } \\
\text { growth } \\
2005(\mathrm{~cm})\end{array}$ & $\begin{array}{l}\text { Average } \\
\text { visual } \\
\text { foliar } \\
\text { rating } \\
(0-5 \text { scale })\end{array}$ & $\begin{array}{l}\text { Average } \\
\text { SPAD }\end{array}$ & $\begin{array}{l}\text { Average } \\
\text { SPAD } \\
\text { change } \\
\text { since } \\
\text { planting }\end{array}$ & $\begin{array}{l}\text { Average } \\
\text { visual } \\
\text { dieback } \\
\text { (percentage } \\
\text { of crown) }\end{array}$ & $\begin{array}{l}\text { Total root } \\
\text { length at } \\
\text { rhizotron } \\
\text { window } \\
(\mathrm{cm})\end{array}$ \\
\hline Gravel/soil & $2.77 a^{*}$ & $0.433 \mathrm{a}$ & $10.13 b$ & $3.83 \mathrm{ab}$ & $42.35 \mathrm{~b}$ & $-6.3 \mathrm{ab}$ & $5.83 \mathrm{a}$ & 1580 \\
\hline Stalite/soil & $2.68 \mathrm{a}$ & $0.283 \mathrm{bc}$ & $9.37 \mathrm{~b}$ & $3.17 \mathrm{bc}$ & $40.63 \mathrm{bc}$ & $-2.3 \mathrm{ab}$ & $12.50 \mathrm{a}$ & 24 \\
\hline Stalite & $2.53 \mathrm{~b}$ & $0.183 \mathrm{c}$ & $2.23 \mathrm{~b}$ & $2.67 \mathrm{c}$ & $36.05 \mathrm{c}$ & $-6.7 \mathrm{ab}$ & $15.83 \mathrm{a}$ & 774 \\
\hline Compacted soil & $2.75 \mathrm{a}$ & $0.350 \mathrm{ab}$ & $7.80 \mathrm{~b}$ & $3.17 \mathrm{bc}$ & $39.15 \mathrm{bc}$ & $-8.6 b$ & $31.67 \mathrm{~b}$ & 37 \\
\hline Noncompacted soil & $2.80 \mathrm{a}$ & $0.417 \mathrm{a}$ & $21.70 \mathrm{a}$ & $4.33 \mathrm{a}$ & $47.47 \mathrm{a}$ & $-0.25 \mathrm{a}$ & $9.17 \mathrm{a}$ & 1415 \\
\hline
\end{tabular}

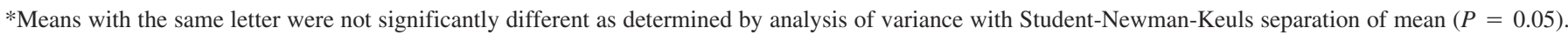

other treatments. There was significantly more dieback in the compacted treatment than any other treatment. Root length at the rhizotrons was much higher in the noncompacted/ suspended pavement, gravel/soil, and Stalite treatments than in the remaining two treatments. Rhizotron root growth data were not statistically analyzed because there was only one rhizotron per treatment.

With the elms (Table 2), there was also significantly more trunk diameter growth in the noncompacted/suspended pavement treatment than with the Stalite and Stalite/soil treatments. Twig growth rates were significantly higher in the noncompacted/suspended pavement and gravel/soil treatments than the other treatments. Visually, the foliar rating of the noncompacted/suspended pavement treatment was significantly better than the Stalite treatment. The SPAD reading of foliar color was significantly higher on the noncompacted/ suspended pavement treatment than all other treatments. There was significantly more dieback in the Stalite treatment than any other treatment. Root length at the rhizotrons was much higher in the noncompacted/suspended pavement treatment.

There were no significant differences in the number of borers or scale insect ratings among treatments. There was no damage to the concrete associated with any tree.
Trees in the Stalite and Stalite/soil treatments exhibited a severe chlorosis within a month of planting. Foliar nutrient analysis found deficiencies in manganese and iron. These micronutrient deficiencies were induced by the high $\mathrm{pH}$ of the Stalite. A mixture of sulfur, iron chelate, and manganese chelate was applied to these treatments. A second application of sulfur was required the next spring on the Stalite treatment. No other fertilizers were applied before measurements were taken.

\section{DISCUSSION}

The trees in the noncompacted/suspended pavement treatment were larger, faster growing, had better color, and more root growth than most of the other treatments. This treatment was followed in tree quality by the gravel/soil treatment. Stalite/soil and compacted soil treatments were overall slightly worse than the gravel/soil treatment. The Stalite treatment was the easiest to install; however, it did not provide a favorable environment for tree growth. The manufacturer of Stalite is investigating the possibility of washing the carbonates from the product to reduce the $\mathrm{pH}$ of the product and potentially improve tree growth quality in the future.

Twig growth data in previous research (Grabosky et al. 2002) found equal or better growth in the CU Soil as com-

Table 2. Bosque lacebark elm (Ulmus parvifolia) conditions 14 months after planting in $200 \mathrm{ft}^{3}$ of soil medium covered with concrete.

\begin{tabular}{|c|c|c|c|c|c|c|c|c|}
\hline Treatment & $\begin{array}{l}\text { Average } \\
\text { trunk } \\
\text { diameter } \\
(\mathrm{cm})\end{array}$ & $\begin{array}{l}\text { Average } \\
\text { diameter } \\
\text { change } \\
\text { since } \\
\text { planting } \\
(\mathrm{cm})\end{array}$ & $\begin{array}{l}\text { Average } \\
\text { twig } \\
\text { growth } 2005 \\
(\mathrm{~cm})\end{array}$ & $\begin{array}{l}\text { Average } \\
\text { visual } \\
\text { foliar } \\
\text { rating } \\
(0-5 \text { scale })\end{array}$ & $\begin{array}{l}\text { Average } \\
\text { SPAD }\end{array}$ & $\begin{array}{l}\text { Average } \\
\text { SPAD } \\
\text { change } \\
\text { since } \\
\text { planting }\end{array}$ & $\begin{array}{l}\text { Average } \\
\text { visual } \\
\text { dieback } \\
\text { (percentage } \\
\text { of crown) }\end{array}$ & $\begin{array}{l}\text { Total } \\
\text { root } \\
\text { length at } \\
\text { rhizotron } \\
\text { window } \\
(\mathrm{cm})\end{array}$ \\
\hline Gravel/soil & $2.35 \mathrm{a}^{*}$ & $0.52 \mathrm{ab}$ & $23.97 \mathrm{a}$ & $3.5 \mathrm{ab}$ & $37.93 \mathrm{~b}$ & $-7.48 \mathrm{ab}$ & $0 \mathrm{a}$ & 3 \\
\hline Stalite/soil & $2.12 \mathrm{~b}$ & $0.28 \mathrm{bc}$ & $11.33 \mathrm{c}$ & $3.0 \mathrm{~b}$ & $36.48 \mathrm{~b}$ & $-0.35 \mathrm{a}$ & $0 \mathrm{a}$ & 0 \\
\hline Stalite & $1.97 \mathrm{~b}$ & $0.15 \mathrm{c}$ & $3.13 \mathrm{~d}$ & $1.0 \mathrm{c}$ & $13.30 \mathrm{c}$ & $-16.80 \mathrm{~b}$ & $6.7 \mathrm{~b}$ & 0 \\
\hline Compacted soil & $2.38 \mathrm{a}$ & $0.52 \mathrm{ab}$ & $17.33 \mathrm{~b}$ & $2.8 \mathrm{~b}$ & $33.95 \mathrm{~b}$ & $-6.28 \mathrm{ab}$ & $0 \mathrm{a}$ & 0 \\
\hline Noncompacted soil & $2.57 \mathrm{a}$ & $0.65 \mathrm{a}$ & $24.73 \mathrm{a}$ & $4.0 \mathrm{a}$ & $44.00 \mathrm{a}$ & $-0.88 \mathrm{a}$ & $0 \mathrm{a}$ & 61 \\
\hline
\end{tabular}

*Means with the same letter were not significantly different as determined by analysis of variance with Student-Newman-Keuls separation of mean $(P=0.05)$. 
pared with close by tree lawn plantings. This sharply contrasts the findings in this study in which twig growth in the noncompacted/suspended pavement treatment was nearly double the second best gravel/soil mix treatment in the cherries. With the elm, the second best twig growth rate was also found in the gravel/soil treatment and was nearly equal to the noncompacted treatment. These differences point to species variability in the response to the soil medium.

Relative chlorophyll content, as measured with a SPAD meter, in a previous study (Grabosky et al. 1998) found slightly higher chlorophyll levels in field grown Acer and Malus that in a CU Soil. However, a higher chlorophyll level was found in the CU Soil treatment than field-grown Tilia. Chlorophyll levels were lower with all three species in the adjacent compacted standard sidewalk profile treatment in that study. Soil pH (8.8 to 9.1) found in the sidewalk base was thought to contribute to the lower chlorophyll content with the compacted sidewalk treatment. In this study, SPAD levels were significantly higher, meaning more chlorophyll, in the noncompacted/suspended pavement treatment than all other treatments with both tree species. Media $\mathrm{pH}(\leq 8.5)$ was also a factor in the Stalite treatment and to a lesser degree in the Stalite/soil treatment. The reason for the differences between the two studies in not obvious.

When designing for planting in spaces that require a solid surface for vehicles and pedestrians, the option of using suspended pavement over noncompacted soil has not received much attention over the past few years. It has been used successfully in places like downtown Charlotte, North Carolina. The differences in tree growth among treatments was dramatic; trees growing in the noncompacted soil suspended pavement treatment are visually healthier in appearance and provide more shade more quickly than any of the other treatments. If suspended pavement is to be used, the pavement will need to be engineered to take expected loads without fracturing. This may require greater reinforcement than pavement installed over structural soil and installation of footers.

The tree growth, maintenance requirements, and pavement damage from the trees in this plot need to be monitored for 10 years.

Acknowledgments. We thank Robert Bartlett, Jr., and the F.A. Bartlett Tree Expert Co. for support of this project; James Urban, Dr. Jason Grabosky, Neil Harley, Dan Thompson, and Don McSween, for technical advice in the layout and construction of the research plot; Jerry Dunaway and Bill Hawkins of BBA Fiberweb and Chuck Fredrick and Debbie Stringer, Carolina Stalite Co., for contributing materials used in the project; Ethan Stewart, Imogene Mole, and Elden LeBrun for assistance with the construction of the plot; Dr. Donald C. Booth for insect evaluations; Dr. Christina Wells at Clemson University for assistance with data analysis; and Laura Johnson and Greg Paige for plot maintenance.

\section{LITERATURE CITED}

Costello, L.R., and K.S. Jones. 2003. Reducing Infrastructure Damage by Tree Roots: A Compendium of Strategies. ISA Western Chapter, Cohasset, CA.

Craul, P.J. 1992. Urban Soil in Landscape Design. John Wiley and Sons, New York, NY.

Grabosky, J., and N. Bassuk. 1995. A new urban tree soil to safely increase rooting volumes under sidewalks. Journal of Arboriculture 21:187-201.

Grabosky, J., N. Bassuk, and B.Z. Marranca. 2002. Preliminary findings from measuring street tree shoot growth in two skeletal soil installations compared to tree lawn plantings. Journal of Arboriculture 28:106-108.

Grabosky, J., N. Bassuk, L. Irwin, and H. van Es. 1998. Pilot study of structural soil materials in pavement profiles. In Watson, G. (Ed.) The Landscape Below Ground II. International Society of Arboriculture, Champaign, IL.

Rolf, K. 1994. Soil compaction and loosening effects on soil physics and tree growth. In Watson, G.W. and D. Neely (Eds.). The Landscape Below Ground. International Society of Arboriculture, Champaign, IL.

E. Thomas Smiley, Ph.D. (corresponding author)

Arboricultural Researcher

Bartlett Tree Research Laboratory

Adjunct Professor, Clemson University

13768 Hamilton Road

Charlotte, NC 28278, U.S.

tsmiley@bartlettlab.com

Lisa Calfee, Ph.D.

Assistant Professor

Queens University

Charlotte, NC, U.S.

Bruce R. Fraedrich, Ph.D.

Director

Bartlett Tree Research Laboratory

Charlotte, NC, U.S.

Emma J. Smiley

Research Technician

Bartlett Tree Research Laboratory

Charlotte, NC, U.S.

Résume. Les arbres entourés de surfaces pavées ont souvent des environnements inhospitaliers pour leur enracinement, ce qui diminue leur espérance de vie. Cet essai a été conçu pour comparer cinq options différentes de type de sol sous les milieux pavés. Ces cerisiers à fleurs japonais (Prunus serrulata) et des ormes à petites feuilles (Ulmus parvifolia) ont été plantés dans des milieux 
de $5,4 \mathrm{~m}^{3}$ contenant du sol compacté, un mélange sol-gravier, du Stalite ${ }^{\mathrm{TM}}$, un mélange de sol avec Stalite, un sol non compacté, et qui a été recouvert d'une couche de béton. Une variété de paramètres de santé et de croissance ont été mesurés 14 mois après. On a découvert que l'accroissement en diamètre du tronc était plus important avec le sol non compacté qu'avec les milieux en Stalite ou en sol-Stalite; que la croissance des pousses était plus importante avec le sol non compacté ou le milieu sol-gravier que tous les autres types de milieux; qu'il y avait un plus haut taux de chlorophylle avec le sol non compacté qu'avec tous les autre types de milieux; et que la croissance racinaire était plus importante avec le sol non compacté (dans le cas de l'orme seulement). La présence de pavage suspendu audessus des sols non compactés produisait les plus importantes augmentation de croissance et résultait en des arbres plus en santé; ces aspects devraient de ce fait être pris en considération lors du design de sites de plantation d'arbres en milieu urbain.

Zusammenfassung. Bäume, die von Pflaster und Straßenbelegen umgeben sind, haben oft ungastliche Wurzelräume, die die Lebenserwartung sehr einschränken. Diese Untersuchung wurde durchgeführt, um 5 verschiedene Bodenkonditionen unter dem Belag zu testen. Prunus serrulata und Ulmus parvifolia wurden in 5,4 qm Pflanzlöcher gepflanzt mit 1. verdichtetem Boden, 2. Kies/BodenGemisch, 3. Stalit, 4. Stalit/Boden oder nicht verdichteten Boden, bedeckt mit Beton. Eine Reihe von Wachstum- und Gesundheitsparametern wurden nach 14 Monaten gemessen. Man fand heraus, dass es mehr Stammdurchmesser bei unverdichtetem Boden als bei Stalit oder Stalit/Boden-Mischungen und mehr Zweigwachstum bei unverdichteten und Kies-Mischungen gab als bei allen anderen. Es gab höhere Chlorophyllraten bei unverdichteten Böden und mehr Wurzelwachstum. Aufgenommenes Pflaster über nicht verdichteten Böden bewirkte größte Freiheit beim Wachstum und Gesundheit der Bäume und sollte bei der Planung künftiger Standort berücksichtigt werden.

Resumen. Los árboles en áreas rodeadas de pavimento con frecuencia tienen ambientes que acortan su esperanza de vida. Este ensayo fue establecido para comparar cinco diferentes opciones de tratamientos al suelo bajo pavimento. El cerezo (Prunus serrulata) y el olmo Bosque ${ }^{\circledR}$ (Ulmus parvifolia) fueron plantados en espacios de 5.4 metros cúbicos (200 cubic feet) con suelo compactado, mezcla de grava/suelo, Stalite ${ }^{\mathrm{TM}}$, y mezcla de Stalite/suelo o suelo no compactado y cubierto con concreto. Una variedad de parámetros de crecimiento y salud fueron medidos después de 14 meses. Se encontró que hubo más crecimiento del diámetro del tronco con tratamiento no compactado que los tratamientos Stalite ${ }^{\mathrm{TM}}$ y mezcla de Stalite/suelo; más crecimiento de rebrotes en suelo no compactado y grava/suelo que en todos los otros; más alta tasa de clorofila en el tratamiento no compactado que en todos los otros; y mayor crecimiento de raíces en los tratamientos no compactados (solamente olmos). El pavimento suspendido sobre suelo no compactado proporcionó una mayor cantidad de crecimiento del árbol y salud y debería ser considerado cuando se diseñen sitios de plantaciones urbanas para árboles. 